\title{
Epileptic seizures in a descendant of Dom Pedro I
}

\author{
Marleide da Mota Gomes', Heber de Souza Maia Filho²
}

\begin{abstract}
Intrauterine seizure is a rare event. Genetic predisposition and trauma are possible risk factors. Objective: To review and comment on the historical description of intrauterine events of a bastard daughter of Dom Pedro I (Maria Isabel Alcântara Brasileira - 18301896). Method: Review of historical facts about the health of Dom Pedro I's daughter according to primary and secondary historical data. Results: According to historical accounts, Dom Pedro l's daughter suffered trauma during the intrauterine period that provoked intrauterine seizures. At the age of eight years, she developed self-limited and benign generalized epilepsy. Like her father, she had mood problems and also learning difficulties. Conclusion: Dona Maria Isabel's own report does not shown sufficient evidence to support the diagnosis of post-traumatic intrauterine seizures. Nevertheless, her family history suggests a genetic basis for her epilepsy.

Key words: epilepsy, genetics, intrauterine convulsions, generalized epilepsy with febrile seizures, plus, history, medicine, Brazil.
\end{abstract}

\section{Crises epilépticas em uma descendente de Dom Pedro I}

\section{RESUMO}

A convulsão intra-uterina é evento raro, sendo possíveis fatores de risco a genética e o traumatismo. Objetivo: Rever e comentar a descrição histórica de eventos intra-uterinas de uma filha bastarda de D. Pedro I (Maria Isabel Alcântara Brasileira - 1830-1896). Método: Revisão dos fatos históricos sobre a saúde da filha do D. Pedro I, de acordo com dados históricos primários e secundários. Resultados: A filha de Dom Pedro I, de acordo com relatos históricos teria sofrido um traumatismo durante o período intra-uterino, o que provocou convulsões intra-uterinas. $\mathrm{Na}$ idade de oito anos a menina desenvolveu uma epilepsia generalizada limitada e benigna. Como seu pai, teve problemas do humor e, também, dificuldades de aprendizagem. Conclusão: $O$ relato de Dona Maria Isabel não gera prova suficiente para sustentar o diagnóstico de convulsões intra-uterinas de origem traumática. Não obstante, seus antecedentes familiares sugerem uma base genética para sua epilepsia. Palavras- chave: epilepsia, genética, convulsão intra-uterina, epilepsia generalizada com convulsões febris plus, história, medicina, Brasil.

\author{
Correspondence \\ Marleide da Mota Gomes \\ Instituto de Neurologia \\ Deolindo Couto - UFRJ \\ Av. Venceslau Braz 95 \\ 22290-140 Rio de Janeiro RJ - Brasil \\ E-mail:mmotagomes@acd.ufr..br \\ Received 8 June 2009 \\ Received in final form 30 August 2009 \\ Accepted 14 September 2009
}

Abnormal intrauterine movements reported by pregnant women, as an expression of epileptic seizures, are apparently rare events, seldom mentioned in the medical literature ${ }^{1,2}$. Such seizures can be related to cortical malformations, maternal opiate abstinence, prenatal deficiency of pyridoxine and vascular or traumatic cerebral injury $^{1,2}$. In this paper, we comment on the descriptive history of a bastard daughter of Dom Pedro I, the first Brazilian emperor, who claimed to have had seizures relating to intrauterine trauma.

\section{Epileptic seizures in a descendant of Dom Pedro I}

Maria Isabel de Alcântara Brasileira, Countess of Iguassu (born in São Paulo,

'MD, PhD, Neurologist, Associate Professor of Neurology (Faculdade de Medicina, Universidade Federal do Rio de Janeiro). Epilepsy Program, Instituto de Neurologia Deolindo Couto, Rio de Janeiro RJ, Brazil; ${ }^{2} \mathrm{MD}$, PhD, Neuropediatrician, Associate Professor of Pediatrics (Universidade Federal Fluminense). Postgraduate Program in Neurology and Neuroscience, Rio de Janeiro RJ, Brazil. 
February 28, 1830; died in Rio de Janeiro, September 13, 1896) was a presumptive daughter of Dom Pedro I and Domitila de Castro Canto e Melo, Marquise of Santos. Maria Isabel's noble title was awarded to her when she married Count Pedro Caldeira Brant. She received nothing from her father, not even paternity recognition. Furthermore, even though a testamentary request for European education was taken care of by the Emperor's second wife, Dona Amélia de Leuchtemberg, this did not take place because of her mother's refusal. The Marquise of Santos, worried about the girl's fragile health, assumed that she would not tolerate the long trip abroad.

$\mathrm{Maul}^{3}$, a biographer of the Countess, criticized Dom Pedro I's character (or lack of it). Describing the illness of the child Maria Isabel (epilepsy), he mentioned that "this was the paternity proof that Nature cried out for in the body of that child, in contradiction to the mockeries with which Pedro I tried to question the Marquise's fidelity". Maria Isabel may have inherited a genetic burden of epilepsy from Dom Pedro I. Maul ${ }^{3}$ presented and reasoned about an autobiographical report in which the Countess correlated her epileptic seizures not only with heredity, but also with an intrauterine trauma that her mother had told her about. The Marquise of Santos, a great enthusiast of the Carnival festivities, had participated in the water wars of the Carnival of 1830, in spite of being pregnant. Among the various activities involving the participants in those events, such as wetting them, they were hit with wax balls filled with water: "little oranges made of wax, hard balls that blew up like grenades on the targeted bodies"3. Maul described how "at the height of the Carnival, one little wax orange hit..." the Marquise's womb "...exactly over the gold piece" (the Marquise habitually wore a gold medal of Our Lady of the Conception with a long chain extending down to womb level). "As the result of this wound, Maria Isabel would say that she was born six days earlier: 'with the impact of the little orange, I received a strong blow to my forehead. From that day onwards, I had convulsions in my mother's womb. I was born with a deformed forehead, imprinted with the image of the medal my mother wore. I was kept confined to a sealed room for one and a half years, protected from the outside air, in order to repair my forehead, because the bone was broken. Happily, no defect was left"'.

It seems that, after this prenatal period, the seizures did not return. There was also no mention of esthetic problems (as can be seen in her picture included in Maul's book $^{3}$ and in the painting by Ferdinand Krumholtz ${ }^{4}$, reproduced in the Figure). Nor was there any mention of any serious neurological outcome (motor delay or paralysis).

The Countess described the beginning of her epilepsy thus: "I was already eight years old when my father's family disease appeared. I had three convulsions in São Pau-

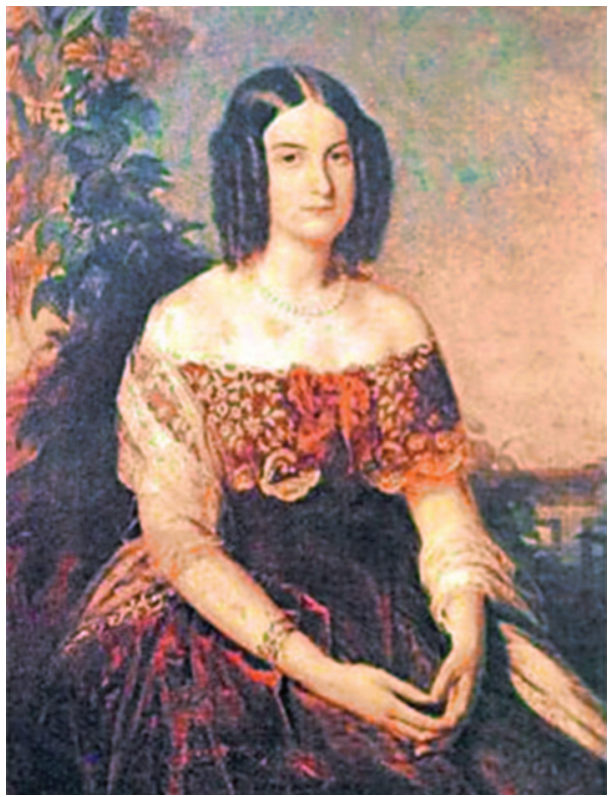

Figure. Painting of the Countess of Iguassu by Ferdinand Krumholtz 1810-18784 (http://www.pitoresco.com.br/laudelino/ krumholz/krumholtz.htm).

lo and nobody, not even Dr. Ellis, thought that I would recover...". Dona Maria Isabel was in fact a "slim and sick" girl who was considered to have tuberculosis by the age of seven years (one year before the first epileptic seizures), but no symptoms of neurotuberculosis (usually fatal at that time) were described. Her health was restored by Dr. Ellis, an English physician of the family. One year after the epilepsy started, the Countess described another seizure, which this time was associated with fever: "... I had a very high fever and convulsions (...) The doctor arrived. I knew I was very sick..." ${ }^{3}$.

The Countess of Iguassu's life followed a course full of sad events, which were considered to be fate, consequent to being "well born and badly predestined". Maul ${ }^{3}$ said that "Maria Isabel must have been (...) a sad child". The Countess was described as "restless, quarrelsome, nervous, wrathful, weak of spirit, spoiled and disobedient". There were also learning problems: "Despite the education that she was given, she was unable to learn much in the schools where she studied, and her degree of culture can be depicted by the style of her writings, with confused letters that are hard to decipher" ${ }^{\prime \prime}$.

\section{DISCUSSION}

The case of the Countess is instructive and demonstrates a possible multifactorial origin for her epilepsy: exogenous and/or only endogenous. Perhaps there is some exaggeration and a touch of romance in her history because of the feelings of rejection and sadness that followed her throughout life. There was no strong evidence 
for any significant intrauterine trauma or intrauterine convulsions. Nor was there any major poor outcome, for instance, forehead deformity, motor deficits or early severe epilepsy. Her first seizure only occurred at the age of eight years. Therefore, the trauma during the intrauterine period should be only taken to be a distant associated factor for the seizures. The Countess did not mention any further epileptic seizures after the febrile seizure at the age of nine years. This indicates that this was a benign form of genetically determined generalized epilepsy. The skull deformity at birth attributed to the episode of the little wax oranges might be better explained as a caput succedaneum or a cephalohematoma. ${ }^{5}$. Both of these are common minor superficial extracranial injuries that need to be differentiated from more serious intracranial lesions such as subgaleal hemorrhages, which are liable to cause seizures. Moreover, the neurological and epileptic prognosis would be expected to be more severe if intrauterine trauma were the main cause of the Countess's epilepsy. It is worth noting that the last epileptic seizure that the Countess described in her memoirs was associated with fever. She was nine years old at that time and therefore outside of the normal age limits for febrile seizures $^{6}$, thus emphasizing the hypothesis of generalized epilepsy with febrile seizures plus ${ }^{7}$.

In summary, Dona Maria Isabel's own report does not shown sufficient evidence to support the diagnosis of post-traumatic intrauterine seizures. Nevertheless, her family history and the benign course of her seizures suggest that she had genetic epilepsy, and probably generalized epilepsy with febrile seizures plus.

ACKNOWLEDGMENTS - We acknowledge the collaboration of the library staff for consultations of books, periodicals and documents (Nacional, Academia de Brasileira de Letras, Real Gabinete Português de Leitura, Instituto Filosofia e Ciências Sociais-UFRJ and Faculdade de Letras-UFRJ) and Museu Imperial - Instituto do Patrimônio Histórico e Artístico Nacional - Ministério da Cultura (archives and library). We acknowledge the collaboration of Professor Alexandra Prufer de Queiroz Campos Araújo (UFRJ) who kindly reviewed the English.

\section{REFERENCES}

1. Baxter P, Kandler R. Benign familial neonatal convulsions: abnormal intrauterine movements, provocation by feeding and ICTAL EEG. Seizure 1997;6:485-486.

2. Bejsovec M, Kulenda Z, Ponca E. Familial intrauterine convulsions in pyridoxine dependency. Arch Dis Child 1967;42:201-207.

3. Maul C. A vida da condessa de Iguassu. Rio de Janeiro: Valverde, 1942.

4. Ferdinando Krumholtz 1810-1878. Retrato da Condessa de Iguaçu (http:// www.pitoresco.com.br/laudelino/krumholz/krumholtz.htm)

5. Parker LA. Early recognition and treatment of birth trauma: injuries to the head and face. Adv Neonatal Care 2005;5:288-297.

6. Dubé CM, Brewster AL, Baram TZ. Febrile seizures: mechanisms and relationship to epilepsy. Brain Dev 2009;31:366-371.

7. Gomes MM, Chalub M. Dom Pedro I of Brazil and IV of Portugal: epilepsy and peculiar behavior. Arq Neuropsiquiatr 2007; 65:710-705. 